\title{
Growth performance and chemical composition of Cirrhinus mrigala (mori) under the effect of chromium chloride hexahydratre
}

\author{
Farkhanda Asad, Samina Qamer*, Ammara Behzad, Tayyaba Ali and
} Asma Ashraf

Department of Zoology, Government College University, Faisalabad-Pakistan

*Corresponding author's email: saminabee@gmail.com

Citation

Farkhanda Asad, Samina Qamer, Ammara Behzad, Tayyaba Ali and Asma Ashraf. Growth performance and chemical composition of Cirrhinus mrigala (mori) under the effect of chromium chloride hexahydratre. Pure and Applied Biology. Vol. 6, Issue 4, pp1226-1233. http://dx.doi.org/10.19045/bspab.2017.600130

Received: 07/07/2017 $\quad$ Revised: 00/00/2017 $\quad$ Accepted: 00/00/2017 $\quad$ Online First: 00/00/2017

\section{Abstract}

A nutritional trial was conducted for 90 days to investigate the effect of different levels of chromium chloride hexahydrate on Cirrhinus mrigala growth and body composition using two types of corn (gelatinized and non-gelatinized). Six test diets were prepared using three levels of chromium chloride hexahydrate $\left(0.0,0.2\right.$ and $\left.0.4 \mathrm{mg} \mathrm{kg}^{-1}\right)$. Fifty Cirrhinus mrigala fingerlings were distributed randomly among six groups each group each with two replicates. The result showed that Cirrhinus mrigala fed on gelatinized corn diet with $0.2 \mathrm{mg} \mathrm{kg}^{-1}$ chromium chloride hexahydrate showed maximum growth as compared to non-gelatinized corn. In case of body composition results revealed that fish fed on gelatinized corn with $0.4 \mathrm{mg} \mathrm{kg}^{-1}$ showed maximum deposition of dry matter, crude fat, crude protein and gross energy while ash retention was observed maximum in non-gelatinized corn with $0.2 \mathrm{mg} \mathrm{kg}^{-1}$. It is concluded and suggested for Cirrhinus mrigala that gelatinized corn and chromium chloride hexahydrate in fish diet are very effective in growth and body composition.

Keywords: Corn; Chromium chloride hexahydrate; Body composition; Growth; Cirrhinus mrigala

\section{Introduction}

Fish is a main source of protein containing essential amino acids and minerals. In socioeconomic fabric of South-Asian countries fish occupies significant position [1]. Fish is a basic nutrient provider that's why world has greatly relied on it. We are facing food shortage now a day especially in the form of protein [2]. For fish culturing intensive and semi-intensive fish cultures are mostly used.
Cirrhinus mrigala with other major carps is commonly cultured in sub-continent. Nutrition is a serious issue in fish farming because it signifies almost $50 \%$ production cost [3]. For feed formulation large amount of seed of animal and plant origin feed is produced in Pakistan. Fish meal is rich source of protein and globally used as dietary protein source in fish feed formulation, but there is some problems in 
using fish meal such as high prices, reduced supply, uneconomical and instability [4]. By replacing fish meal with plant meals production rate can be increased with low cost, plant meals contains low phosphorous contents and easily available [5].Carbohydrates are cheaper dietary energy source, digestion of carbohydrates depends on fish species such as herbivorous and omnivorous can better utilize carbohydrates [6].

Gelatinization of carbohydrates is performed it increase growth, palatability and digestibility of feed. As a result of gelatinization swelling of granules and hydration happens that increases digestibility, palatability and susceptibility of starch granules to enzymes. Due to gelatinization starch molecules are more susceptible to enzymes and increase in size [7]. Sunflower oil and cod liver oil are used in fish feed as a source of lipid [8]. Different methods have been used in past to get maximum growth and better body composition such as phytase supplementation, chromic oxide, chromium picolinate, chromium yeast, chromium chloride hexahydrate, chromium polynicotine, chromium carbochelate and probiotic inclusion etc. Using various compounds of chromium with different graded levels a little work is performed on major carps. In this trial chromium chloride hexahydrate was added in fish feed for better growth rate and chemical composition. Chromium is a vital micro mineral it plays important role in the nutritional and physiological responses in fishes [9]. Chromium is found in various valence forms $\mathrm{Cr}^{+2}$ to $\mathrm{Cr}^{+6}$ [10]. Mostly trivalent and hexavalent forms of chromium are found in our environment. Hexavalent form of chromium is a powerful oxidizing agent; it reacts with carbohydrates, amino acid and protein and $\mathrm{Cr}^{+6}$ can easily crosses the biological membranes [11]. Mostly fish feed supplemented with trivalent and hexavalent forms of chromium because it is involved in protein, carbohydrate and lipid metabolism [12]. More research work is required to expose the effect of chromium chloride hexahydrate on fish growth and chemical composition. Therefore, this research work was planned to determine the effect of inorganic chromium (chromium chloride hexahydrate) on growth and body composition of Cyprinus carpio.

\section{Materials and methods}

This experiment was carried out in fish research lab, department of Zoology, Government College University Faisalabad Pakistan.

\section{Experimental fish and acclimatization}

The fingerlings of Cirrhinus mrigala (1 to 2 inches) were bought from fish seed hatchery, Satiana road Faisalabad, Pakistan. Before starting experimental trial $C$. mrigala fingerlings were acclimatized for two weeks with feed $\mathrm{T} 2\left(\mathrm{NG} / 0.0 \mathrm{Cr}_{2} \mathrm{Cl}_{3} \cdot 6 \mathrm{H}_{2} \mathrm{O} \mathrm{mg} / \mathrm{kg}\right)$. After acclimatization period experimental diets were given to $C$. mrigala fingerlings at $4 \%$ live wet body weight.

\section{Experimental design}

This experimental trial was carried out for 90 days. After acclimatization 600 fingerlings of uniform size were allocated to six aquaria each with two replicate. For replica of each treatment aquaria were divided into halves. These aquariums having dimension $90 \mathrm{~cm} \mathrm{~L} \times 30 \mathrm{~cm} \mathrm{~W} \times 45 \mathrm{~cm} \mathrm{H}$ with 29L water capacity. Using air pumps with capillary system oxygen was supplied to the system (5-6ppm) and was monitored on daily basis. Fecal matter collection and manual water exchange were also performed daily.

Feed Ingredients and Preparation of Experimental Diets

Six experimental diets were prepared with various graded levels of chromium chloride hexahydrate and corn ( $\mathrm{G} \& \mathrm{NG})$. Corn was grounded to make powder then add suitable 
amount of water to make it dough, placed this dough in autoclave at 15 psi for 60 minutes to get maximum gelatinization. After gelatinization of corn this mass was placed in oven at $60^{\circ} \mathrm{C}$ for one hour. The dried mass was positioned on hammer mill having $0.5 \mathrm{~mm}$ screen and then stockpiled in air tights jars until use. Corn was used as a carbohydrate source. Gelatin and casein were used in fish feed as a source of protein while lipid sources were sunflower oil and cod liver oil. All dry ingredients weighted carefully, ground and mixed thoroughly and add sufficient amount of water $(50 \mathrm{ml})$ to make it dough mix this mixture for half an hour. Spread this mixture in tray then placed in oven for drying purpose [13]. This material was grounded to make pellets (2 $\mathrm{mm})$. Pellets were steamed for five minutes. These pellets were dried at $60^{\circ} \mathrm{C}$ in oven. Chromic oxide was added in experimental diets as an inert marker at the rate of $1 \%$ of total diet. Six test diets were prepared supplemented with carbohydrates (G/NG) and different graded levels of chromium chloride hexahydrate; T1 (G/0.0 mg Kg-1), T2 (NG/ $0.0 \mathrm{mg} \mathrm{Kg}^{-1}$ ), T3 (G/0.2 $\mathrm{mg} \mathrm{Kg}^{-1}$ ), T4 (NG/0.2mg Kg-1), T5 (G/0.4 mg Kg $\left.{ }^{-1}\right)$ and T6 (NG/0.4 mg $\left.\mathrm{Kg}^{-1}\right)$. Using linear formulation method all experimental diets were prepared through winfeed 2.6 (Winfeed U.K) ltd., Cambridge,U.K).

\section{Feeding protocol}

After acclimatization of two weeks $C$. mrigala fingerlings were shifted to six glass aquaria each with a replicate. Every aquarium had fifty fingerlings of uniform size dispersed arbitrarily. Experimental diets were given to $C$. mrigala fingerlings at the rate of $4 \%$ live wet body weight [14] twice a day.

\section{Fecal collection}

On daily basis $C$. mrigala fingerlings were shifted in partitioned aquaria after feeding period of three hours for collection of fecal matter. By siphoning with care fecal matter was collected and dried at room temperature on daily basis. For all chemical analysis enough quantity of fecal matter required that's why continued fecal collection for 120 days.

\section{Growth studies}

On fortnight basis morphometric characteristics i.e. body weight (g) and total body length $(\mathrm{cm})$ of $C$. mrigala, fifteen from each treatment were measured. Total length was measured from tip of mouth to the anterior tip of tail fin using $30 \mathrm{~cm}$ ruler. Weight balance was used to measure body weight. The fingerlings were shifted into their particular aquaria again after recording all data. The growth of fingerlings was determined by following calculations:

\section{i. Increase in wet body weight (g) by following formula}

Average body weight of $1^{\text {st }}$ observed fortnight - Average body weight of next observed fortnight.

ii. Increase in net total body length (cm) Average body length of $1^{\text {st }}$ observed fortnight - Average body length of next observed fortnight

\section{iii. Specific growth rate (SGR) evaluated by using the following formula}

SGR $=\underline{\text { In (Final wet body weight) }- \text { In (Initial wet body weight) }} \times 100$ (Time duration (Days)

vi. Weight gain $=$ Final weight - initial weight

\section{Analytical method}

Required samples of experimental diets and body meat of all replicates were homogenized using mortar pestle distinctly and analyzed chemically by AOAC (1990) protocols; for dry matter at $1050 \mathrm{C}$ oven drying, for crude protein microkjeldhal apparatus, gross energy by oxygen bomb calorimeter, electric furnace for ash and chloroform methanol extraction method [15] through 10454 soxtec system HTz for crude fat extraction. 


\section{Statistical analysis}

At the end of experiment obtained data of growth and body composition was subjected to one-way analysis of variance, ANOVA. The differences among means were compared by Tukey's honesty significant difference test and considered significant difference test $\mathrm{P}<0.05$.

\section{Results}

This nutritional trial showed following results for growth and body composition of C. mrigala.

\section{Growth performance}

The results of growth performance are given in table 1 that showed maximum body weight gain $(6.42 \mathrm{~g})$, increase in body length $(2.63 \mathrm{~cm})$ and specific growth rate $(0.77)$ in experimental group-T3 that was treated with gelatinized corn diet with chromium chloride hexahydrate at level of $0.2 \mathrm{mg} \mathrm{kg}^{-1}$ (Table 2). T3 showed significant $(\mathrm{P}<0.05)$ variations with other treated groups.

\section{Body composition}

Table 3 show the effect of chromium chloride hexahydrate with $\mathrm{G}$ and NG carbohydrates source on body meat composition of $C$. mrigala. It was found that maximum deposition of nutrients dry matter, crude lipid, crude protein and gross energy values were observed in experimental gropT5 in which fish was fed with diet G/0.4 mg $\mathrm{Kg}^{-1}$ chromium chloride hexahydrate, while ash contents deposition were found maximum in experimental group-T4treated with non-gelatinized corn at chromium chloride hexahydrate level $0.2 \mathrm{mg} \mathrm{Kg}{ }^{-1}$ (Table .3). Discussion

\section{Growth performance}

In the present study dietary supplementation with chromium chloride hexahydrate showed maximum values for body weight, total body length and specific growth rate (Table.2). This experimental group-T3 includes gelatinized corn and $0.2 \mathrm{mg} \mathrm{Kg}^{-1}$ level of chromium chloride hexahydrate.
These results are in accordance with [16] who reported that that maximum growth was observed in common carp fed on feed containing $0.5 \mathrm{mg} \mathrm{kg}^{-1} \mathrm{Cr}$. Similar findings were reported by [17] who concluded that Labeo rohita fingerlings fed on dietary chromium picolinate $\left(0.8 \mathrm{mg} \mathrm{Kg}^{-1}\right)$ showed maximum weight gain. While conflicting results were found by [18] who suggested that there is no positive effect of dietary chromium picolinate on growth performance of tilapia. Our results are in agreement with [9] who indicated that grass carp fingerlings fed on $0.8 \mathrm{mg} \mathrm{Kg}^{-1}$ chromium showed maximum increase in body weight. Gelatinized corn improves digestibility and utilization of carbohydrates that results better growth performance and chromium is involved in carbohydrate metabolism.

Specific growth rate (SGR) was also found maximum in group-T3 $\left(\mathrm{G} / 0.2 \mathrm{mg} \mathrm{kg}{ }^{-1}\right.$ $\left.\mathrm{Cr}_{2} \mathrm{CO}_{3} \cdot 6 \mathrm{H}_{2} \mathrm{O}\right)$ in the present study (Table.2). Similar findings were reported by [16] who concluded that SGR value is highest in common carp at level of $0.5 \mathrm{mg}$ $\mathrm{kg}^{-1}$ dietary chromium. However contradictory consequences were observed by [18] who stated that Cr-pic had no positive effect on value of specific growth rate. Gelatinized corn and chromium chloride hexahydrate increased metabolism and improved growth rate of fishes.

\section{Body composition}

The achieved results of body composition showed that chromium chloride hexhydrate at level of $0.4 \mathrm{mg} \mathrm{kg}^{-1}$ had positive effect on dry matter deposition in group-T5 (Table.3). Similar findings were reported by [8] who concluded that at level of $0.3 \mathrm{mg} \mathrm{Kg}{ }^{-1}$ $\mathrm{Cr}_{2} \mathrm{CO}_{3} .6 \mathrm{H}_{2} \mathrm{O}$ maximum deposition of dry matter was observed in Labeo rohita. Our results are consistent with the results of [19] who stated that maximum dry matter deposition in dorsal muscles of Nile tilapia at level of $400 \mathrm{ug} \mathrm{kg}^{-1}$. 
Table 1. Growth performance of Cirrhinus mrigala fed on various experimental diets

\begin{tabular}{|c|c|c|c|c|c|c|}
\hline \multirow[t]{2}{*}{ Parameters } & T1 & $\mathbf{T 2}$ & T3 & T4 & T5 & T6 \\
\hline & $\begin{array}{c}\left(\mathrm{G} / 0.0, \mathrm{Cr}_{2} \mathrm{Cl}_{3} .\right. \\
\left.6 \mathrm{H}_{2} \mathrm{O} \mathrm{mg} / \mathrm{kg}\right)\end{array}$ & $\begin{array}{c}\left(\mathrm{NG} / 0.0, \mathrm{Cr}_{2} \mathrm{Cl}_{3} .\right. \\
\left.\mathrm{H}_{2} \mathrm{O} \mathrm{mg} / \mathrm{kg}\right)\end{array}$ & $\begin{array}{c}\left(\mathrm{G} / 0.2, \mathrm{Cr}_{2} \mathrm{Cl}_{3} .\right. \\
\left.6 \mathrm{H}_{2} \mathrm{O} \mathrm{mg} / \mathrm{kg}\right)\end{array}$ & $\begin{array}{c}\left(\mathrm{NG} / 0.2, \mathrm{Cr}_{2} \mathrm{Cl}_{3} .\right. \\
\left.6 \mathrm{H}_{2} \mathrm{O} \mathrm{mg} / \mathrm{kg}\right)\end{array}$ & $\begin{array}{c}\left(\mathrm{G} / 0.4, \mathrm{Cr}_{2} \mathrm{Cl}_{3} .\right. \\
\left.6 \mathrm{H}_{2} \mathrm{Omg} / \mathrm{kg}\right)\end{array}$ & $\begin{array}{c}\left(\mathrm{NG} / 0.4, \mathrm{Cr}_{2} \mathrm{Cl}_{3} .\right. \\
\left.6 \mathrm{H}_{2} \mathrm{O} \mathrm{mg} / \mathrm{kg}\right)\end{array}$ \\
\hline Initial weight (g) & $3.59 \pm 0.1601^{\mathrm{mn}}$ & $3.23 \pm 0.025^{\mathrm{n}}$ & $4.20 \pm 0.235^{\mathrm{j}-\mathrm{n}}$ & $4.63 \pm 0.550^{\mathrm{h}-\mathrm{n}}$ & $4.3 \pm 0.445^{i-n}$ & $4.09 \pm 0.480 \mathrm{k}^{-\mathrm{n}}$ \\
\hline Final weight (g) & $6.67 \pm 0.665^{d-j}$ & $5.16 \pm 0.155^{\mathrm{g}-\mathrm{n}}$ & $10.62 \pm 0.68^{\mathrm{a}}$ & $7.13 \pm 0.430^{\mathrm{b}-\mathrm{g}}$ & $9.55 \pm 0.050^{\mathrm{ab}}$ & $8.35 \pm 0.500^{\mathrm{a}-\mathrm{e}}$ \\
\hline Weight gain (g) & $3.01 \pm 0.11^{\mathrm{D}}$ & $1.93 \pm 0.13^{\mathrm{F}}$ & $6.42 \pm 0.21^{\mathrm{A}}$ & $2.50 \pm 0.08^{\mathrm{E}}$ & $5.25 \pm 0.07^{\mathrm{B}}$ & $4.26 \pm 0.16^{\mathrm{C}}$ \\
\hline Initial length $(\mathbf{c m})$ & $6.41 \pm 0.210^{\mathrm{k}}$ & $6.90 \pm 0.095^{\mathrm{ijk}}$ & $7.61 \pm 0.070^{\mathrm{g}-\mathrm{k}}$ & $7.75 \pm 0.250^{\mathrm{f}-\mathrm{k}}$ & $7.82 \pm 0.385^{f-j}$ & $7.60 \pm 0.210^{\mathrm{g}-\mathrm{k}}$ \\
\hline Final length $(\mathrm{cm})$ & $9.00 \pm 0.060^{\mathrm{a}-\mathrm{f}}$ & $8.24 \pm 0.030^{\mathrm{d}-\mathrm{I}}$ & $10.24 \pm 0.465^{\mathrm{a}}$ & $9.03 \pm 0.215^{\mathrm{a}-\mathrm{f}}$ & $9.96 \pm 0.215^{\mathrm{ab}}$ & $9.48 \pm 0.365^{\mathrm{a}-\mathrm{e}}$ \\
\hline Increase in length $(\mathrm{cm})$ & 2.59 & 1.34 & 2.63 & 1.28 & 2.14 & 1.88 \\
\hline SGR & $0.50 \pm 0.02^{\mathrm{D}}$ & $0.39 \pm 0.01^{\mathrm{E}}$ & $0.77 \pm 0.03^{\mathrm{A}}$ & $0.35 \pm 0.01^{\mathrm{E}}$ & $0.66 \pm 0.02^{\mathrm{B}}$ & $0.59 \pm 0.02^{\mathrm{C}}$ \\
\hline
\end{tabular}

Table 2. Percentage composition of experimental diet (G\&NG/CrCl $\left.\mathrm{G}_{3} 6 \mathrm{H}_{2} \mathrm{O} \mathrm{mg} / \mathrm{Kg}\right)$

\begin{tabular}{|c|c|c|c|c|c|c|}
\hline \multirow{2}{*}{$\begin{array}{c}\text { Components } \\
(\%)\end{array}$} & T1 & $\mathbf{T 2}$ & T3 & T4 & T5 & T6 \\
\hline & $\begin{array}{c}(\mathrm{G} / 0.0 \\
\mathrm{Cr}_{2} \mathrm{Cl}_{3} . \\
\left.6 \mathrm{H}_{2} \mathrm{O} \mathrm{mg} / \mathrm{kg}\right)\end{array}$ & $\begin{array}{c}\left(\mathrm{NG} / 0.0, \mathrm{Cr}_{2} \mathrm{Cl}_{3} .6 \mathrm{H}_{2} \mathrm{O}\right. \\
\mathrm{mg} / \mathrm{kg})\end{array}$ & $\begin{array}{c}\left(\mathrm{G} / 0.2, \mathrm{Cr}_{2} \mathrm{Cl}_{3} .\right. \\
\left.6 \mathrm{H}_{2} \mathrm{O} \mathrm{mg} / \mathrm{kg}\right)\end{array}$ & $\begin{array}{c}\left(\mathrm{NG} / 0.2, \mathrm{Cr}_{2} \mathrm{Cl}_{3} \cdot 6 \mathrm{H}_{2}\right. \\
\mathrm{O} \mathrm{mg} / \mathrm{kg})\end{array}$ & $\begin{array}{c}\left(\mathrm{G} / 0.4, \mathrm{Cr}_{2} \mathrm{Cl}_{3} \cdot 6 \mathrm{H}_{2} \mathrm{Om}\right. \\
\mathrm{g} / \mathrm{kg})\end{array}$ & $\begin{array}{c}\left(\mathrm{NG} / 0.4, \mathrm{Cr}_{2} \mathrm{Cl}_{3} .6\right. \\
\left.\mathrm{H}_{2} \mathrm{O} \mathrm{mg} / \mathrm{kg}\right)\end{array}$ \\
\hline Casein & 30.57 & 30.57 & 30.57 & 30.57 & 30.57 & 30.57 \\
\hline Gelatin & 8 & 8 & 8 & 8 & 8 & 8 \\
\hline Corn Flour & 42.43 & 42.43 & 42.43 & 42.43 & 42.43 & 42.43 \\
\hline Cellulose & 7 & 7 & 7 & 7 & 7 & 7 \\
\hline Sunflower oil & 8 & 8 & 8 & 8 & 8 & 8 \\
\hline Carboxymethyl cellulose & 1 & 1 & 1 & 1 & 1 & 1 \\
\hline Vitamin premix & 2.60 & 2.60 & 2.60 & 2.60 & 2.60 & 2.60 \\
\hline Chromic oxide & 1 & 1 & 1 & 1 & 1 & 1 \\
\hline B.H.T & 0.02 & 0.02 & 0.02 & 0.02 & 0.02 & 0.02 \\
\hline Chromium Chloride Hexa hydrate $(\mathrm{mg} / \mathrm{kg})$ & 0.0 & 0.0 & 0.2 & 0.2 & 0.4 & 0.4 \\
\hline
\end{tabular}

${ }^{1}$ Casein fat free: $70 \% \mathrm{CP}$ (Himedia ltd, India); ${ }^{2}$ Gelatin: 90\%CP (Himedia ltd, India); ${ }^{3}$ Purchased from local market, Faisalabad, Pakistan. ${ }^{4}$ Sigma Chemical, St. Louis, MO, USA. ${ }^{5}$ Composition of vitamins mineral mix (Quantity/Kg): Vitamin A, 15M.I.U; Vitamin $\mathrm{D}_{3}$, 3M.I.U; Vitamin B 1 ,5000mg; Vitamin E, 6000 IU; Vitamin $\mathrm{B}_{2}$, 6000mg; Vitamin $\mathrm{K}_{3}$, 4000mg, Vitamin $\mathrm{B}_{6}$, 4000mg; Folic acid, $750 \mathrm{mg}$; Vitamin $\mathrm{B}_{12}$, $9000 \mathrm{mg}$; Calcium pantothenate, 10000mg; VitaminC, $15000 \mathrm{mg}$; Nicotinic acid, $25000 \mathrm{mg}{ }^{6}$ The antioxidant ButylatedHydoxy Toluene was added at $0.02 \%$ of the added oil.

Table 3. Comparison of means for body composition of Cirrhinus mrigala fed on different test diets

\begin{tabular}{|c|c|c|c|c|c|c|}
\hline \multirow[t]{2}{*}{ Components } & T1 & T2 & T3 & T4 & T5 & T6 \\
\hline & $\begin{array}{l}\left(\mathrm{G} / 0.0, \mathrm{Cr}_{2} \mathrm{Cl}_{3}\right. \\
\left.6 \mathrm{H}_{2} \mathrm{O} \mathrm{mg} / \mathrm{kg}\right)\end{array}$ & $\begin{array}{r}\left(\mathrm{NG} / 0.0, \mathrm{Cr}_{2} \mathrm{Cl}_{3}\right. \\
\left.6 \mathrm{H}_{2} \mathrm{O} \mathrm{mg} / \mathrm{kg}\right)\end{array}$ & $\begin{array}{l}\left(\mathrm{G} / 0.2, \mathrm{Cr}_{2} \mathrm{Cl}_{3} .\right. \\
\left.6 \mathrm{H}_{2} \mathrm{O} \mathrm{mg} / \mathrm{kg}\right)\end{array}$ & $\begin{array}{c}\left(\mathrm{NG} / 0.2, \mathrm{Cr}_{2} \mathrm{Cl}_{3} .\right. \\
\left.6 \mathrm{H}_{2} \mathrm{O} \mathrm{mg} / \mathrm{kg}\right)\end{array}$ & $\begin{array}{l}\left(\mathrm{G} / 0.4, \mathrm{Cr}_{2} \mathrm{Cl}_{3} .\right. \\
\left.6 \mathrm{H}_{2} \mathrm{Omg} / \mathrm{kg}\right)\end{array}$ & $\begin{array}{c}\left(\mathrm{NG} / 0.4, \mathrm{Cr}_{2} \mathrm{Cl}_{3} .\right. \\
\left.6 \mathrm{H}_{2} \mathrm{O} \mathrm{mg} / \mathrm{kg}\right)\end{array}$ \\
\hline Dry matter (\%) & $95.10 \pm 0.10^{\mathrm{A}}$ & $96.15 \pm 0.15^{\mathrm{A}}$ & $95.00 \pm 2.00^{\mathrm{A}}$ & $96.00 \pm 3.00^{\mathrm{A}}$ & $97.50 \pm 0.50^{\mathrm{A}}$ & $95.50 \pm 1.50^{\mathrm{A}}$ \\
\hline Ash $(\%)$ & $86.05 \pm 1.05^{\mathrm{BC}}$ & $87.15 \pm 0.15^{\mathrm{ABC}}$ & $84.50 \pm 0.50^{\mathrm{C}}$ & $89.50 \pm 1.50^{\mathrm{A}}$ & $88.50 \pm 0.50^{\mathrm{AB}}$ & $85.00 \pm 1.00^{\mathrm{C}}$ \\
\hline Crude Lipid (\%) & $27.20 \pm 0.20^{\mathrm{AB}}$ & $25.15 \pm 0.15^{\mathrm{B}}$ & $31.00 \pm 1.00^{\mathrm{AB}}$ & $27.50 \pm 1.50^{\mathrm{AB}}$ & $38.00 \pm 1.00^{\mathrm{A}}$ & $26.50 \pm 4.50^{\mathrm{B}}$ \\
\hline Crude Protein (\%) & $29.69 \pm 0.010^{\mathrm{B}}$ & $32.83 \pm 0.020^{\mathrm{AB}}$ & $33.06 \pm 1.810^{\mathrm{AB}}$ & $35.15 \pm 0.780^{\mathrm{AB}}$ & $37.50 \pm 2.125^{\mathrm{A}}$ & $32.03 \pm 0.780^{\mathrm{AB}}$ \\
\hline Gross Energy $\left(\mathrm{Kcal} \mathrm{g}^{-1}\right)$ & $581.05 \pm 8.69^{\mathrm{B}}$ & $579.43 \pm 8.43^{\mathrm{B}}$ & $606.26 \pm 16.32^{\mathrm{AB}}$ & $596.60 \pm 14.84^{\mathrm{AB}}$ & $654.46 \pm 8.76^{\mathrm{A}}$ & $582.75 \pm 17.34^{\mathrm{AB}}$ \\
\hline
\end{tabular}


In case of ash highest value was recorded in experimental group-T4 (Table.3). However Contradictory results were found by [9] stated that Cr-pic had non-significant effect on ash retention in grass carp. Maximum value of crude lipid deposition in fish body meat was found in group-T5 $\left(\mathrm{G} / 0.4 \mathrm{mg} \mathrm{kg}^{-1}\right.$ $\mathrm{Cr}_{2} \mathrm{CO}_{3} .6 \mathrm{H}_{2} \mathrm{O}$ ) (Table.3). Similar results were reported by [8] which concluded that at level of $0.5 \mathrm{mg} \mathrm{kg}^{-1}$ chromium chloride hexahydrate maximum crude lipid deposition occur in Labeo rohita. [1] Reported that at level of $0.54 \mathrm{mg} \mathrm{kg}^{-1}$ lipid contents were highest in fish body. Chromium chloride hexahydrate and gelatinized carbohydrates had positive effects on lipids contents because both are involved in increasing digestibility and metabolism of fishes.

In case of crude protein significant variation were observed among different treatments and in experimental group-T5 maximum deposition of crude protein was recorded (Table 3). Results of other researchers like $[8,18,20]$ favors the current study they stated that chromium had beneficial effect on nutrient crude protein retention in fish body meat. While dissimilar results were reported by [21] who concluded that Lcartinine had no positive effect on body meat of tilapia.

In this study gross energy values were significantly different among various treatments and maximum value of gross energy was observed for group-T5 which contains $0.4 \mathrm{mg} \mathrm{kg}^{-1}$ chromium chloride hexahydrate and gelatinized corn (Table 3). These results are in accordance with [8] who concluded that chromium chloride hexahydrate at level of $0.5 \mathrm{mg} \mathrm{kg}^{-1}$ had beneficial effect on gross energy values for Labeo rohita.

\section{Conclusions}

The obtained results of present research work showed that chromium chloride hexahydrate with gelatinized corn at level of
$0.2 \mathrm{mg} \mathrm{kg}$ showed maximum growth performance of Cirrhinus mrigala while chromium chloride hexahydrate at level of $0.4 \mathrm{mg} \mathrm{kg} \mathrm{kg}^{-1}$ showed positive effects on chemical composition of $C$. mrigala. High protein profile fish can be produced by using gelatinized corn with $0.4 \mathrm{mg} \mathrm{kg}{ }^{-1}$ level of chromium in future. A little research work had done using chromium chloride hexahydrate in fish feed more research is needed in this field.

\section{Authors' contributions}

Conceived and designed the experiments: F Asad, Performed the experiments: A Behzad, F Asad \& S Qamer, Analyzed the data: S Qamer \& T Ali, Contributed reagents/ materials/ analysis tools: T Ali \& A Ashraf, Wrote the paper: F Asad \& A Behzad.

\section{References}

1. Khabade S (2015). Study of gut contents of major carps for their food habits from Sidddhewadi lake of Tasgaon tahsil of Sangli district Maharashtra. International Journal of Fisheries and Aquatic Studies, 2(4), 1-4.

2. Khan KJ, Khan N, Rasool F, Ullah S \& Hassan S (2015). Apparent digestibility of selected plant based ingredients and their impacts on body composition of Mori, Cirrhinus mrigala.

3. Craig S \& Helfrich L (2012). Understanding Fish Nutrition, Feeds and Feeding, Cooperative Extension Service, publication 420-256. Virginia State University, USA.

4. Shapawi R, Ebi I, Yong A, Chong M \& Chee K, Sade A (2013). Soybean meal as a source of protein in formulated diets for tiger grouper, Epinephelus fuscoguttatus juvenile. Part II: Improving diet performances with phytase supplementation. Journal of Agricultural Science, 4, 19-24.

5. Dalsgaard J, Ekmann KS, Pedersen PB, \& Verlhac, V (2009). Effect of 
supplemented fungal phytase on performance and phosphorus availability by phosphorus-depleted juvenile rainbow trout (Oncorhynchus mykiss), and on the magnitude and composition of phosphorus waste output. Aquaculture, 286(1), 105-112.

6. Krogdahl A, Hemre Gi and Mommsen T (2005). Carbohydrates in fish nutrition: digestion and absorption in postlarval stages. Aquaculture nutrition, 11(2), 103-122.

7. Yengkokpam S, Sahu N, Pal A, Mukherjee S \& Debnath D (2007). Gelatinized carbohydrates in the diet of Catla catla Fingerlings: effect of levels and sources on nutrient utilization, body composition and tissue enzyme activities. Asian Autralasian Journal of Animal Sciences,20(1), 89.

8. Asad F, Naseem N, Ashraf A, Ali T \& Behzad A (2017). Chemical composition and growth performance of Labeo rohita under the influence of Chromium chloride hexahydrate marker. International Journal of Biosciences, 10(1), 186-194.

9. Liu T, Wen H, Jiang M, Yuan D, Gao P, Zhao Y \& Liu W (2010). Effect of dietary chromium picolinate on growth performance and blood parameters in grass carp fingerling, Ctenopharyngodon idellus. Fish physiology and biochemistry, 36(3), 565-572.

10. Lushchak VI (2011). Environmentally induced oxidative stress in aquatic animals. Aquatic Toxicology, 101(1), 13-30.

11. Pechova A \& Pavlata L (2007). Chromium as an essential nutrient: a review. Vet. MedCzech, 52, 1-18.

12. Pires KA, Dos Santos DCC, Graca DS, Melo MM, Barbosa FA \& Soto-Blanco B (2015). Effects of Two Sources of Chromium on Performance, Blood and
Liver Lipid Levels in Nile Tilapia (Oreochromis niloticus). Acta Scientiae Veterinariae, 43, 1302.

13. Kumar V, Sahu N, Pal A, Jain K, Kumar S, Sagar V \& Ranjan J (2012). Gelatinized and Non- gelatinized corn starch based diet influence the fatty acid profile in the liver of tropical freshwater fish, Labeo rohita. Journal of Aquaculture Research \& Development, 2:106.

14. Noreen US, M (2008). Determination of nutrient digestibility and amino acid availability of various feed ingredients for Labeo rohita. International journal of agriculture and biology, 10(5), 551555.

15. Blight Egd \& W.J (1959). A rapid method of total lipid extraction and purification. Candian Journal of Biochemistry and Physiology, 3, 911917.

16. Ahmad AR (2012). The effect of dietary chromium (III) on growth and carbohydrate utilization in mirror and common carp (Cyprinus carpio)L.

17. Giri AK, Sahu NP, Saharan N \& Dash G (2014). Effect of dietary supplementation of chromium on growth and biochemical parameters of Labeo rohita (Hamilton) fingerlings. Indian Journal of Fisheries, 61(2), 7381.

18. Mehrim IA (2012). Effect of dietary chromum picolinate supplementation on growth performance, carcass composition and organ indices of Nile Tilapia (Oreochromis niloticus L.) fingerlings. Journal of Fisheries and Aquatic Science, 7, 224-232.

19. Mehrim A (2014). Physiological, biochemical andhistomeric responses of Nile tilapia (Oreochromis niloticus L.) by dietary organic chromium (chromium picolinate) supplementation. 
Journal of Advance Search. Journal of Advance Search, 5, 303-310.

20. Magzoub MB, Al-Batshan HA, Hussein MF, Al-Mufarrej SI \& Al-Saiady MY (2010). The effect of of source and level of dietary chromium supplementation on performance, chemical composition and some metabolic aspects in hybrid tilapia fish (Oreochrois niloticus $\times$ O.aureus). Res. J. Biol. Sci, 5, 164-170.

21. Dias J, Arzel J, Corraze G \& Kaushik J (2001). Effects of dietary L-carnitine supplementation on growth and lipid metabolism in European seabass (Dicentrachus labrax). Aquaculture res, 32(1), 206-215. 